\title{
The Effect of Handep Cooperative Learning Model on Social Skill and Motivation to Learn Mathematics
}

\author{
Demitra, Sarjoko \\ Faculty of Teacher Training and Education \\ Universitas Palangkaraya \\ Palangkaraya, Indonesia \\ demitra_pahan@ymail.com
}

\begin{abstract}
The aim of this research was to evaluate the effect of Handep cooperative learning model to the student's social skill and motivation in mathematics learning. It was conducted through the posttest only control group design. The sample were 68 students of sixteen to seventeenth years old, selected from the population of 309 students. The results showed that there was the significant difference social skill and motivation in learning mathematics of students who learned using handep cooperative learning model than those who learned by using conventional teaching model. In other words, the students who were taught by using handep achieved higher social skill and motivation than those who learned by using conventional teaching model. The results of the study have implications for the selection method of learning mathematics in school that teachers, need to pay attention to aspects of the cultural background of students. The application of the cooperation model of mutual help in the study of mathematics material backed with reflective questions in teaching materials.
\end{abstract}

Keywords- Handep Cooperative Learning, Social Skills, Motivation, Mathematics Learning.

\section{INTRODUCTION}

The cultural background plays an important role in the learning of mathematics. The cultural background influences the thinking of mathematics [1]. Reference [2] finds that the ideas of all cultural groups generate mathematical ideas, reference [3] find the cultural practice to be richer in mathematics learning. Reference [4] finds that the cultural practices can be seen to be an influencing factor in promoting this ability. Students in the class is a representation of the communities, which have a cultural background. The Dayak tribe communities in Borneo of Indonesia, have long been working together in a traditional mutual help and cooperation called handep [5], [6].

In order to improve the students understanding on mathematics, the research inspired the handep mechanism of mutual cooperation, as basis to construct a cooperative learning model. Handep cooperative learning model as a model of teaching [7] has several components of scenario, model orientation, objective and assumption, key concept, and teaching model. Teaching including components of syntax, social system, principle of reaction, support system model, instructional impacts and nurturant impacts.

The results of design and development of handep cooperative learning model through expert validation of education technology in 2010 year showed that the components of a scenario, the syntax, the principle of reaction, the support systems, and the applications have all been eligible as a learning model. The expert predicted that the instructional and nurturant impacts would reach above $85 \%$. The handep cooperative learning model which has been developed and revised as well as expert recommended before, needs to be tried out in a field test [8]

The handep cooperative learning model validations has been done to a small group of students of Mathematics Education Study Programs of Teacher Training and Education Faculty of University of Palangka Raya in CentralKalimantan, Indonesia. The validations through observation showed that the handep cooperative learning model had fulfilled: (a) the components of cooperative learning [9] respectively by $98.68 \%$ and $96.7 \%$, (b) the principles of effective learning [10] of $95.59 \%$ and $95.60 \%$ and the rules of Quantum Teaching [11] by $75 \%$ and $87.50 \%$. The nurturant impact such as social skills respectively achieved $86.60 \%$. The expert recommended field tests of the handep cooperative learning model in schools to test the effectiveness and attractiveness of handep cooperative learning model [9].

The attractiveness was focused on the analysis of the effect of handep cooperative learning model toward the social skills and motivation. Is it the handep cooperative learning model was able to motivate the students to learn mathematics and develop the social skill? Is it the social skills and motivation to mathematics learning of students who learned using handep cooperative learning model higher than the conventional teaching?

Social skills and motivation is affective domain as implications of application the instructional model. Handep cooperative learning using for develop social skill. Social skills is the one important element of cooperative learning. References [12] and [13] said develop social skills is a goal of cooperative learning. Dimensions of social skills such are cooperation/collaboration, team capability, and communication [14], [15]. Research finding of [16] showed that the cooperative learning give effect to social skills at a good level, that including, interest and intention to join the team activity, giving opinions, accepting others', and determination to work.

Cooperative learning model can develop motivation to learn mathematics. References [17], [18] finding, that implementation of cooperative learning in classroon can improve motivation of students. Research of [19] found that 
there are two type of motivation, intrinsic and extrinsic motivations. That type of motivation formed inside, and other formed outside of individual. The factor of intrinsic motivation, that the pleasure-oriented motivation played a strongly positive role than the factor of extrinsic motivation productivity-oriented motivation in students' achievement of mathematics.

\section{METHOD}

The research was carried out using the posttest only control group design [20]. Mathematics instruction used handep cooperative learning model was applied in the treatment group, and those using conventional teaching was applied in the control group. The 68 students as sample were selected by cluster random sampling from the population of 309 students. The sample students were divided into 34 students as a treatment group and 34 students as a control group.

The researchers and teachers did the mathematics instruction in a team teaching. They conducted a workshop to develop the lesson plan and learning materials. The workshop have been done to explain the syntax of handep cooperative learning and conventional teaching to the mathematics teachers, the determination of learning materials, the design of lesson plans and worksheets, and peer-teaching.

The instruments used consisted of rubrics of social skill assessment, and questionnaire on motivation to learn mathematics. The social skill rubrics including three components i.e. the attitude of having mutual respect to each other, helped each other, and skill of suggested opinions. The rubric had four levels of social skill $(1=$ very poor, $2=$ poor, 4 $=$ good, $5=$ very good). Social skill get through classroom observation. The achievement motivation questionnaire have reliability coefficient of $\alpha-$ Cronbach of 0.73 . Data analysis including descriptive statistic, t-test, and of homogeneity assumption using the Levene test, used SPSS-17.

\section{RESULT}

Handep cooperative learning model was developed based on [7] structure of models of teaching that consisted of scenario, orientation of model, objective and assumption, keynote concept, and teaching model. The variables of instructional objective were problem solving ability and mathematical concept mastery. The variables of nurturing impact were social skill and motivation.

The syntax of handep cooperative learning model includes: (1) understanding of the initial ability; (2) dividing the students into teams of 3-4 students; (3) each member in team reflect his/her problem individually; (4) each member present his/her problem to others in team and discuss it to get meaningful understand about the problem deeply; (5) the team make an agreement about the sequence of solve the problem; (6) the team solve the individual problem together, one by one in turns; (7) the team evaluate the solution; (8) the team present the solution and celebrate their success [8].
Result of research focused on analysis the effect of handep cooperative learning compared to conventional teaching, on that is social skill and motivation, as presented below.

\section{A. Social skill}

Table 1 presents the mean score of students' social skill after they learned using handep cooperative learning model and those using conventional teaching. The mean of students' social skill who learned using handep cooperative learning model was 10.44. The social skill mean of students who learned with conventional teaching model was 8.74.

TABLE I. THE MEAN AND STANDARD DEVIATION OF SOCIAL SKILLS

\begin{tabular}{|c|c|c|c|}
\hline Teaching Models & $\mathbf{N}$ & Mean & $\begin{array}{c}\text { Standard } \\
\text { Deviation }\end{array}$ \\
\hline Handep cooperative learning & 34 & 11.62 & 1.46 \\
\hline Conventional teaching & 34 & 8.97 & 1.31 \\
\hline
\end{tabular}

Homogeneity test and mean difference presented in Table 2. Levene's test for equality of variances yielded $F=0.52$, and $\mathrm{p}=0.47$, which indicates that the data of social skills has homogeneous variance. The mean difference of social skill showed through value of $t=7.87$, and significant at $\mathrm{p}=0.00$. The mean of experiment group higher than the mean of control group. Research finding based on this analysis is the social skills of students taught using handep cooperative learning model higher than conventional teaching model. The social skills consist of attitude of having mutual respect to each other, helped each other, and skill of suggested opinions of students taught using handep cooperative learning model better than the conventional teaching.

TABLE II. HOMOGENEITY TEST AND TEST OF DIFFERENCE MEAN

\begin{tabular}{|c|c|c|c|c|c|c|c|c|c|}
\hline & \multicolumn{2}{|c|}{$\begin{array}{c}\text { Levene's Test } \\
\text { for Equality } \\
\text { of Variances }\end{array}$} & \multicolumn{5}{|c|}{ t-test for Equality of Means } & \multicolumn{2}{|c|}{$\begin{array}{c}95 \% \\
\text { Confidence } \\
\text { Interval of } \\
\text { the } \\
\text { Difference }\end{array}$} \\
\hline & $\mathrm{F}$ & Sig. & $\mathrm{t}$ & df & $\begin{array}{l}\text { Sig. } \\
(2- \\
\text { tailed) }\end{array}$ & $\begin{array}{c}\text { Mean } \\
\text { Differe } \\
\text { nce }\end{array}$ & $\begin{array}{c}\text { Std. } \\
\text { Error } \\
\text { Differen } \\
\text { ce }\end{array}$ & $\begin{array}{c}\text { Low } \\
\text { er }\end{array}$ & Upper \\
\hline $\begin{array}{c}\text { Equal } \\
\text { variances } \\
\text { assumed }\end{array}$ & .52 & .47 & $\begin{array}{c}7.8 \\
7\end{array}$ & 66 & .00 & 2.65 & .34 & 1.98 & 3.32 \\
\hline
\end{tabular}

\section{B. Motivation}

The attractiveness of handep cooperative learning model may be shown by the visible impact of that model on student's motivation. Student's motivation to learn rational exponent concept of mathematics taught using handep cooperative learning model and those using conventional model is presented in Table 3. Motivation to learn of students who learned using handep cooperative learning model resulted in mean of 50.68, while the motivation to learn of students who learned using conventional teaching model resulted in mean of 47.24. 
TABLE III. THE MEAN AND STANDARD DEVIATION OF MOTIVATION SCORES.

\begin{tabular}{|c|c|c|c|}
\hline Teaching Models & $\mathrm{N}$ & Mean & Standard Deviation \\
\hline Handep cooperative learning model & 34 & 50.68 & 2.72 \\
\hline Conventional teaching & 34 & 47.24 & 3.65 \\
\hline
\end{tabular}

Levene's test for homogeneity assumption test yielded $\mathrm{F}$ value of Levene's test of $0.85, p=0.08$. This value shows that the data of motivation to learn of students of both groups had homogenous variance. Table IV presents the value $t=4.41$, at significant of $p=0.00$, which shows there is a different of motivation to learn of students who learned using handep cooperative learning model and those using conventional teaching. The finding of research based on this analysis, that student's motivation through handep cooperative learning model is higher than conventional teaching.

\section{TABLE IV. HOMOGENEITY TEST AND THE TEST OF DIFFERENCE MEAN.}

\begin{tabular}{|c|c|c|c|c|c|c|c|c|c|}
\hline & $\begin{array}{c}\text { Levene's } \\
\text { Test for } \\
\text { Equality of } \\
\text { Variances }\end{array}$ & \multicolumn{9}{|c|}{ t-test for Equality of Means } & \multicolumn{2}{|c|}{$\begin{array}{c}\text { 95\% Confidence } \\
\text { Interval of the } \\
\text { Difference }\end{array}$} \\
\hline & $\mathrm{F}$ & Sig. & $\mathrm{t}$ & $\mathrm{df}$ & $\begin{array}{c}\text { Sig. } \\
(2- \\
\text { tailed })\end{array}$ & $\begin{array}{c}\text { Mean } \\
\text { Differ- } \\
\text { ence }\end{array}$ & $\begin{array}{c}\text { Std. } \\
\text { Error } \\
\text { Dif- } \\
\text { ference }\end{array}$ & Lower & Upper \\
\hline $\begin{array}{c}\text { Equal } \\
\text { variances } \\
\text { assumed }\end{array}$ & 3.28 & .08 & 4.41 & 66 & .00 & 3.44 & .78 & 1.88 & 4.99 \\
\hline
\end{tabular}

\section{DISCUSSION}

Handep cooperative learning model designed to develop the mathematics problem solving skill and mastery of concepts. The nurturing effect would be risen as the result of implementation the handep cooperative learning are social skill and motivation to mathematics learning. The finding of research, presented that handep cooperative learning influence students social skill and motivation. This finding proved that teaching and learning model can be develop base on mutual cooperation culture of community. As well as the research finding in some cultural context of [1], [2], [3], [4]

Handep cooperative learning model has more advantages in facilitating the process of collaboration. Collaboration process is facilitated with steps in syntax of cooperative team. The impact of steps in cooperative team can facilitate the students to elaborate their cognitive by peer modeling and assessment. Reference [21] explained that the process of cooperative learning can enhance learning by elaborated explanations, peer modeling, cognitive elaboration, peer practice, peer assessment and correction.

Various ability in team and rotation help each other mechanism can provide scaffolding for students. Students can ask and discussion to their friends in team, who high ability in mathematics. Students who have less ability can learn the difficult material from other students in the group who understand the material more. In this context, social skill to be developing naturally. Reference [13], cooperative and collaborative process are the way to enhance the students' thinking. References [12] and [22] said, cooperative learning can help students with low and high abilities work together in order to finish their task. The students with high ability can tutored to the students with low ability.

Problem solving in mathematics to be challenge for students in learning mathematics. Handep cooperative learning provide for help them solve the problem. The mutual cooperation to motivate students solve their individual problem together. Problem solving through handep cooperation to encourage students help each other and give them to express their opinion, in order to develop the reasoning strategy, metacognition to optimize the reflective thinking. Social skill developed through this condition. When the students help each other in team, they learn accepting to other [16] and they become positive interdependence in team [9]. When students express their opinion, face-to-face interaction and sharing their knowledge can be happen. It is make interpersonal intelligence can improve better.

The research finding showed that motivation to learn mathematics of students learning using handep cooperative learning model better than conventional teaching model. This result is relevant to [21], [17], and [18] in which cooperative learning can motivate the students to learn. When students in team to discuss their problem, they have motivation to solve the problem. Student low ability can learn to other student high ability of mathematics. They thinking aloud, to exertion, never give up, found solution of their individual problem, together. Extrinsic motivation productivity-oriented motivation become grows in this process. And also the pleasure-oriented motivation to be risen, such as look happy to learn to solve math problems, they are vigorous discussion and do not look burden while studying. Reference [19] found that the kind of motivation is indicators have strongly positive role to mathematics achievement.

\section{CONCLUSIONS}

Mutual cooperation of a tribe to be a based to design and development cooperative learning model. Handep cooperative learning model implementation in mathematics classroom context, risen the good social skill in team working and motivation to solve mathematics problem. In order to improve mathematics problem solving skill, handep cooperative learning is a model alternative that can use in every context of curriculum.

Implication of research, teacher should monitoring the reflective thinking process and encourage discussion within the group, and also manage the time allocation as possible. Students need the sufficient time allocation to understand the problem, thinking aloud to find solution through discussion and help each other.

\section{REFERENCES}

[1] S. Sharma, "Influence of culture on secondary school students' understanding pf statistic: a fijian persfective," Statistic Education Research Journal, vol. 13, no. 2, pp. 104-117, 2014.

[2] A. J. Bishop, "Cultural conflicts in mathematics education: developing a research agenda," For the Learning of Mathematics, vol. 14, no. 2, pp. 


\section{5-18, 1994.}

[3] A. Bose and V. K. Kanta, "Influence of socio-economic backgroud and cultural practices on mathematics education in India: a contemporary overview in historical perspective," ZDM Mathematics Education, vol. 46, no. 7, 2014.

[4] G. Shuaibu, "Cultural practices and mathematical thinking ability among Hausa and Yoruba secondary school students in Kano and Oyo State, Nigeria," Journal of Technical Education and Training, vol. 6, no. 2, pp. 56-72, 2014.

[5] Mubyarto, Desa-Desa di Kalimantam: Studi Konstruksi Desa di Wilayah Kalimantan Tengah (Villages in Kalimantan: Study of Villages Construction in Remote Areas of Central Kalimantan\}, Yogyakarta, Indonesia: Aditya Media, 1993.

[6] H. Bunu, Pendidikan dalam Konstruksi Masyarakat SUku Dayak ot Danum, Kalimantan (Education in COmmunity Construction of Dayak Ot Danum Tribe, Borneo), Surabaya, Indonesia: Jenggala Pustaka Utama, 2011.

[7] B. Joyce, M. Weill and E. Calhoun, Models of Teaching, Yogyakarta, Indonesia: Pustaka Pelajar, 2009.

[8] Demitra, Sarjoko and S. K. Uda, "Pengembangan model pembelajaran kooperatif handep untuk pembelajaran matematika dan sains (research and development of handep cooperative learning model for mathematics and sciences teaching and learning)," Jurnal Pendidikan dan Pengajaran, vol. 19, no. 1, pp. 15-27, 2012.

[9] G. M. jacobs, G. S. Lee and J. Ball, Learning Cooperative Via Cooperative, Singapore, Republic of SIngapore: SEAMEO Regional Language Center Singapore, 1996.

[10] Merril, "First Principal of Instruction," in Instructional Design Theories and Models: Building a Common Knowledge Based Vol III, New York, Routledge, 2009, pp. 41-68.

[11] B. DePorter, M. Reardon and S. S. Nourie, Quantum Teaching: Orchestrating Student Succes, Boston, Mass: Pearson, 1998.

[12] R. I. Arrends, Classroom Instruction and Management, New York: McGraw Hill, 1997.

[13] S. Sharan, The Handbook of Cooperative Learning, Westport, Conn: Praeger Paperback, 1999.

[14] M. N. Ishak, M. H. Z. Abidin and A. Y. A. Bakar, "Dimensions of SOcial Skills and Their Relationship with Empathy among Gifted and Talented Students in Malaysia," in Proceeding of 5th World Conference on Educational Sciences, Roma, Italy, Madrid, Spain, 2014.

[15] B. L. Martin and C. M. Reigeluth, "Affective Education and Affective Domain: Implication for Instructional-Design Theories and Models," in Instructional-Design Theories and Models New Pradigm of Instructional Theory Volume II, Mahwah, Lawrence Erlbaum Associates, 1999, pp. 485-510.

[16] A. Pattawana, S. Prasarnpanich and R. Attanawong, "Enhancing Primary School Student's Social Skills Using Cooperative Learning in Mathematics," in Proceeding of International Conference on Education \& Educational Psychology 2013, Antalya, Turky, London, United Kingdom, 2013.

[17] F. B. Entonado and S. M. Garcia, "Co-operative learning in the teaching of mathematics in secondary education," Educational Action Research, vol. 11, no. 1, pp. 93-120, 2003.

[18] D. Sulisworo and F. Suryani, "The effect of cooperative learning, motivation and information technology literacy to achievement," International Journal of Learning and Development, vol. 4, no. 2, pp. $58-64,2014$.

[19] Y. Zhu and F. K. S. Leung, "Motivation and achievement: is there an East Asian," International Journal of Science and Mathematics Education, vol. 9, no. 5, pp. 1189-1212, 2011.

[20] D. T. Campbell and J. C. Stanley, Experimental and QuasiExperimental Design for Research, Chicago: Rand McNally and
Company, 1963.

[21] R. E. Slavin, "Research on Cooperative Learning and Achievement: What wWe Know, What We Need to Know," 1995. [Online]. Available: PB Socialfamily535.pbwork.com/f/slavin1996(1).pdf.

[22] Wagiran, "Meningkatkan keaktifan mahasiswa dan menghilangkan miskonsepsi melalui pembelajaran konstruktivistik model kooperatif berbantuan modul (increasing students' activity and reducing misconception through cooperative constructivistic model using modules)," Jurnal Ilmu Pendidikan, vol. 13, no. 1, pp. 25-32, 2006. 